\title{
Effects of low-protein diets supplemented with antioxidants on histopathology of testis and testosterone and performance of male Japanese quail (Coturnix coturnix japonica)
}

\author{
Hamid Mahmoodpour ${ }^{1}$, Sina Vahdatpour ${ }^{1}$, Mohamadali Jafargholipour ${ }^{2}$, Tohid Vahdatpour ${ }^{3^{*}}$ \\ ${ }^{1}$ Islamic Azad University, Tabriz Branch, Faculty of Veterinary Medicine, Tabriz, Iran. \\ 2 Agricultural Research Education and Extension Organization, Razi Vaccine and Serum Research Institute, Department of Research and \\ Development, Marand, Iran. \\ ${ }^{3}$ Islamic Azad University, Shabestar Branch, Faculty of Animal and Veterinary Sciences, Department of Physiology, Shabestar, Iran.
}

\begin{abstract}
The present study sought to examine the effects of low-protein diets supplemented with natural and synthetic antioxidants on reproductive traits and performance of male Japanese quail. A total of 144 one-day-old quail chicks were randomly assigned to receive four different treatments, including a control diet (a basal diet) without antioxidant supplementation, low-protein diet without antioxidant supplementation, low-protein diet supplemented with the E-selenium antioxidant (a combination of vitamin E and selenium), and low-protein diet supplemented with the antioxidant Loxidan (a combination of propyl galat, ethoxyquin, and citric acid). Throughout the study, feed and water were provided ad libitum from one to 45 days of age. Performance values were calculated at the end of the experimental period. Blood samples were collected from the wing vein of six male birds randomly selected from each treatment group. Subsequently, blood samples were used to measure serum testosterone levels by ELISA. A total of 36 slides were prepared from testes of 12 adult quail for histological studies. Results from this study showed that there was a significant increase in blood testosterone levels of quail fed the antioxidant Loxidan. An increased number of spermatogonia was found in quail fed both antioxidants. In addition, a significant increase was found in the number of spermatid cells in quail fed a low-protein diet with antioxidants. Surprisingly, spermatozoa cells showed a significant elevation in quail fed antioxidants as compared with those fed low-protein diets. Interestingly, a significant increase was observed in the final body weight of the quail fed antioxidants. Therefore, it can be deduced that antioxidant intake not only can improve reproductive indices, such as testosterone levels and testicular tissue in Japanese quail, but is also useful for performance of quail fed low-protein diets.
\end{abstract}

Key Words: E-selenium, Loxidan, performance, protein, quail, testis, testosterone

\section{Introduction}

Free radicals, considered as highly unstable molecules, are typically associated with atoms containing one or more unpaired electrons (Surai, 2007). The reactive capacity of such molecules makes them capable of damaging biologically relevant molecules such as DNA, proteins, lipids or carbohydrates. This means that cell components, especially cell membranes, nucleus, and nucleic acids, are potentially vulnerable to oxidative stress-induced damage (Pryor et al., 2006). Damage to DNA is associated with

\section{Received: June 11, 2016 \\ Accepted: October 25, 2016 \\ *Corresponding author: tvahdatpour@gmail.com \\ http://dx.doi.org/10.1590/S1806-92902017000200007}

How to cite: Mahmoodpour, H.; Vahdatpour, S.; Jafargholipour, M. and Vahdatpour, T. 2017. Effects of low-protein diets supplemented with antioxidants on histopathology of testis and testosterone and performance of male Japanese quail (Coturnix coturnix japonica). Revista Brasileira de Zootecnia 46(2):123-129.

Copyright (C) 2017 Sociedade Brasileira de Zootecnia. This is an Open Access article distributed under the terms of the Creative Commons Attribution License (http://creativecommons.org/licenses/by/4.0/), which permits unrestricted use, distribution, and reproduction in any medium, provided the original work is properly cited. mutations, translation errors, and disruption of protein synthesis; more importantly, in some cases, DNA damage leads to cancer (Surai, 2003). Oxidative stress can especially damage tissues, such as testis, due to their high rates of metabolism and cell replication, emphasizing the potential role of antioxidant capacity in such tissues (Turner and Lysiak, 2008). It is widely established that a number of conditions or events associated with male infertility can potentially induce oxidative stress. Testicular oxidative stress seems to be a common feature in male infertility, highlighting the need to develop new treatment strategies for clinically relevant cases of hypospermatogenesis; in light of this, antioxidant therapy seems to be an effective, cost-effective, and safe way to control such diseases. A fall in dietary protein intake not only decreases plasma proteins and their antioxidant effects either directly or indirectly, but also adversely affects fertility. On the other hand, oral administration of antioxidants has been demonstrated to reduce negative effects of reduced protein diets (Turner and Lysiak, 2008). The antioxidant system of the body has the ability to prevent damaging effects of free radicals and the toxic products of their metabolism. Biological antioxidants, 
such as vitamin $\mathrm{C}$, vitamin $\mathrm{E}$, and selenium, react with free radicals or precursor metabolites and convert them into less reactive molecules, leading to the delay or prevention of oxidation of biological molecules (Surai, 2007; Baylan et al., 2010). It is increasingly appreciated that diet plays a pivotal role in maintaining animal health, productivity, and reproductive performance of farm animals and poultry. Among a variety of dietary factors, natural antioxidants are of special importance to maintain high growth rates, reproduction, and immunocompetence in poultry production (Surai, 2007). Poultry producers are interested in using low-protein diets to minimize feed cost and the amount of nitrogen excreted in litter (Tarasewicz et al., 2006; Kamran et al., 2008; Kamran et al., 2010). Nevertheless, reduced protein diets result in negative effects such as decrease in the rate and efficiency of growth and carcass proteins, as well as an increase in carcass fat contents, etc. (Kamran et al., 2008). Additionally, a decrease in serum proteins, resulting from reduced protein diets, leads to elevated freeradical activities (Surai, 2007) (Figure 1). Dietary proteins protect quail against damaging effects of aflatoxins and other possible side effects. Because of their ability to reduce damaging effects of aflatoxins, antioxidants compensate for the lack of proteins in quail diets (Kamran et al., 2010). In the present study, the efficacy of E-selenium (a combination of vitamin $\mathrm{E}$ and selenium) and Loxidan (a combination of propyl galat, ethoxyquin, and citric acid) was evaluated as natural and synthetic antioxidants, respectively. Vitamin E, which is found in high quantities in vegetable oils, was first proposed in 1992 as a reproductive vitamin. Vitamin $\mathrm{E}$ is currently used during stressful

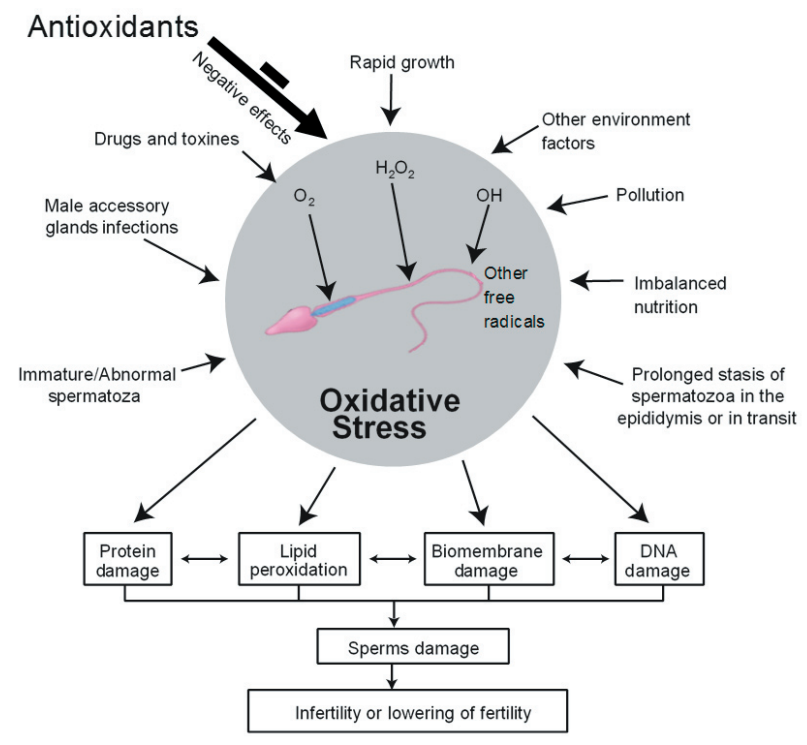

Figure 1 - Effects of oxidants and antioxidants on production and fertility of poultry sperms. laboratory conditions of spermatozoa processing, including dilution, storage, freezing, and melting (Surai et al., 2002). Since its discovery, several studies have demonstrated that vitamin $\mathrm{E}$ deficiency results in impaired fertility in humans and lab animals. However, the effects of vitamin E deficiency or of its supplementation on the fertility of poultry species have been less well studied (Rengaraj and Hong, 2015). Selenium, an essential trace element, plays important roles in growth, immune function, productivity, and anti-stress potential. The need for selenium may change in stress conditions, such as low-protein intake. It is well-documented that dietary selenium supplementation improves feed efficiency, minimizes changes of blood biochemical parameters, elevates antioxidant activities, and decreases lipid peroxidation products in stressed birds (Fan et al., 2009; Canogullari et al., 2010).

Literature survey revealed that there is still no report to address the effects of antioxidant intake in low-protein diets in Japanese quail and other poultry. Therefore, the objective of the present study was to investigate the effects of low protein diets supplemented with natural and synthetic antioxidants on reproductive traits and performance of male Japanese quail.

\section{Material and Methods}

The protocol of this experiment use is in accordance with the laws and regulations of animal protection and was approved by ethical committee from Islamic Azad University.

A total of 144 one-day-old quail chicks with a mean body weight of $7.78 \pm 0.39 \mathrm{~g}$ were obtained from Damavand Quail Co. Flock. The quail were randomly assigned to 12 pens with 12 birds per pen, allowing floor space of $0.015 \mathrm{~m}^{2}$ per bird; the pens were randomized with respect to feed additives (Figure 2). The ambient temperature was maintained at $35^{\circ} \mathrm{C}$

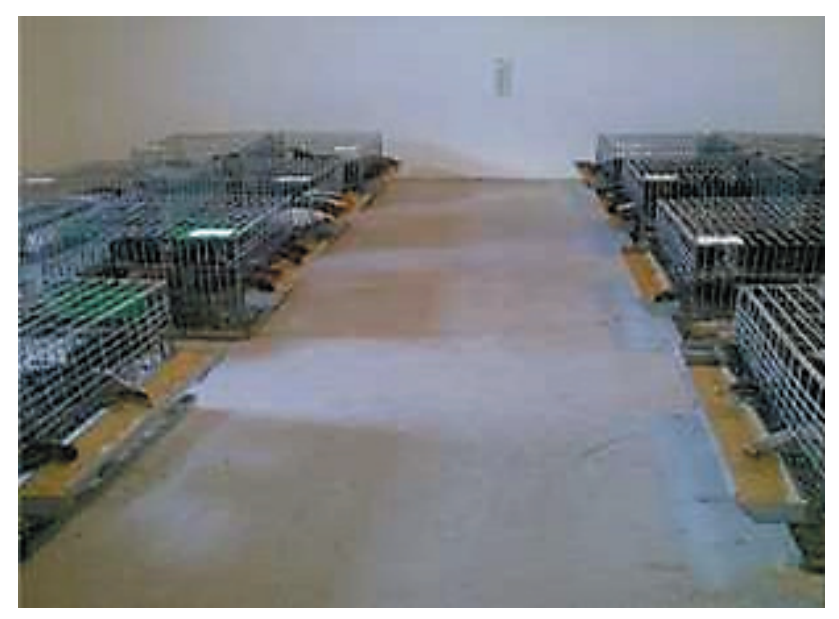

Figure 2 - Experimental room used for Japanese quail. 
for the first five days and then gradually reduced, according to normal management practices, to $22{ }^{\circ} \mathrm{C}$. Throughout the experiment, the light-dark cycle was $22 \mathrm{~h}$ of light followed by $2 \mathrm{~h}$ of dark (light intensity of $2.5 \mathrm{w} / \mathrm{m}^{2}$ ). All birds were kept under the same standard environmental, hygiene, and managerial conditions, according to the NRC (1994).

The experiment was conducted under completely randomized design, with four different treatments and three replicates. The nutrient composition of diets for quail from one to 45 days of age was according to the NRC recommendations. The birds were fed a standard starter ration from one to 28 days of age, followed by the finisher ration from 29 to 45 days of age (Table 1). To avoid the interference of other factors in the outcome, no supplements or vitamins were added to the diets. The quail were divided into four groups of 36 quail; groups 1 to 4 received a control diet (a balanced diet formulated according to the recommendations of NRC (1994)) without antioxidant supplementation, low-protein diet (15\%) without antioxidant supplementation, low-protein diet (15\%) supplemented with the antioxidant E-selenium (at a dose of $1 \mathrm{~g} / \mathrm{kg}$ ), and low-protein diet (15\%) supplemented with Loxidan TD 30, an antioxidant which protects feed and its pre-stages against the oxidative spoilage of materials sensitive to oxidation with activity of $26 \%$ ethoxyquin, $7 \%$ propyl gallate, and $4 \%$ citric acid (at a dose of $0.2 \mathrm{~g} / \mathrm{kg}$ ), respectively. During the fed state, all birds were given ad libitum access to balanced diets from one to 45 days of age.

Feed intake of each experimental cage was recorded separately. The total body weight (BW) of birds in each cage and feed conversion ratio (FCR) were calculated at the end of the experimental period ( 45 days). The mortality were recorded on a daily basis. The final BW and weight of testis of a sample bird were recorded individually before and after slaughtering, respectively, and presented as a percentage of live body weight. At 45 days of age, blood samples were collected in the fasting state by cervical dislocation of two males per pen $(n=24)$. Blood samples were immediately centrifuged at $5000 \mathrm{rpm}$ for $5 \mathrm{~min}$ and sera were stored at $-20^{\circ} \mathrm{C}$ until analysis. The commercial ELISA kit (T ELISA Kit MBS9305135, My Biosource, California, USA) was used to determine serum testosterone levels in ELISA systems (Awareness Technology Stat Fax ${ }^{\circledR}$ 2100 Microplate Reader and Awareness Technology Stat Fax $^{\circledR} 2600$ Microplate Washer). Afterwards, the birds were processed by removing the head, neck, shanks, and feet and eviscerated by cutting around the vent and carefully removing the viscera. Carcass yield (dressing percentage) was obtained by expressing the dressed carcass weight as a percentage of live body weight (Vahdatpour and Babazadeh, 2016; Vahdatpour et al., 2009).

To determine the changes in the testicular density, testis tissues were fixed in Bouin's solution for two days, dehydrated through graded concentrations of ethanol, embedded in paraffin wax, sectioned at $5-\mu \mathrm{m}$ thicknesses, and stained with Mayer's Hematoxylin and Eosin (H\&E) using a standard staining protocol (Khakpour et al., 2012).

The data were analyzed using an analysis of variance (ANOVA) with the general linear model (GLM) procedure of SAS (Statistical Analysis System, version 8.2). Different means were compared with Duncan's multiple Range test at $\mathrm{P}<0.05$ (Duncan, 1955).

Table 1 - Ingredient and analyzed composition of basal diets

\begin{tabular}{|c|c|c|c|c|}
\hline Ingredient $^{1}$ & $\begin{array}{c}\text { Starter } \\
\text { (1-28 days) }\end{array}$ & $\begin{array}{c}\text { Starter } \\
(15 \% \text { reduction in protein })\end{array}$ & $\begin{array}{c}\text { Finisher } \\
(29-45 \text { days })\end{array}$ & $\begin{array}{l}\text { Finisher } \\
(15 \% \text { reduction in protein })\end{array}$ \\
\hline Corn grain & 46 & 57.1 & 51.6 & 60.3 \\
\hline Soybean meal & 46.7 & 36.1 & 36.0 & 27.5 \\
\hline Di-calcium phosphate & 2.0 & 2.2 & 2.0 & 2.2 \\
\hline Sunflower oil (without antioxidant) & 2.5 & 1.3 & 3.5 & 2.6 \\
\hline DL-methionine & 0.3 & 0.4 & 0.4 & 0.5 \\
\hline Total (\%) & 100 & 100 & 100 & 100 \\
\hline \multicolumn{5}{|l|}{ Nutrient } \\
\hline Metabolizable energy (kcal/kg) & 2920 & 2920 & 2920 & 2920 \\
\hline Crude protein $(\%)$ & 24.5 & 20.8 & 20.3 & 17.3 \\
\hline Calcium $(\%)$ & 1.4 & 1.4 & 3.0 & 3.0 \\
\hline
\end{tabular}

${ }^{1}$ To prevent the entry and intervention of non-experimental antioxidants such as vitamin $\mathrm{E}, \mathrm{A}$, and $\mathrm{C}$ and minerals such as selenium in the basal diet, vitamin and mineral premix were not used in present experiment. 


\section{Results and Discussion}

Mean feed intake of birds (Table 2) showed that there were no significant differences between different treatments. Feed intake in birds fed the low-protein diet without antioxidant supplementation was $595 \mathrm{~g}$, showing an insignificant increase compared with the control group with $587 \mathrm{~g}$. The mean feed intake showed a numerical increase when compared with the group fed a low-protein diet without antioxidant supplementation and the control group. Results from this study showed that antioxidant intake failed to exhibit a significant positive effect on mean feed intake. Some studies showed that low levels of dietary protein are able to decrease feed intake in breeder and broiler quail (Tarasewicz et al., 2006; Tarasewicz et al., 2007). However, Kamran et al. (2008) reported that lowprotein diets severely increase feed intake in broilers. In addition, Oliveira et al. (2013) revealed that reduced crude protein diets failed to influence feed intake in broilers. Fan et al. (2009) demonstrated that daily supplementation with different concentrations of selenium lack the ability to affect feed intake in broilers.

The results from this study (Table 2) showed that FBW was significantly reduced $(\mathrm{P}<0.05)$ with decreased protein levels in the diet, showing a decrease from $178 \mathrm{~g}$ in controls to $174 \mathrm{~g}$ (low protein diet without antioxidants).

Table 2 - Effects of treatments on performance values of quail at 45 day of age

\begin{tabular}{lcccc}
\hline Treatment & $\begin{array}{c}\text { Feed intake } \\
(\mathrm{g})\end{array}$ & $\begin{array}{c}\text { Final body weight } \\
(\mathrm{g})\end{array}$ & $\begin{array}{c}\text { Feed conversion } \\
\text { ratio }(\mathrm{g} / \mathrm{g})\end{array}$ & $\begin{array}{c}\text { Dressing } \\
(\%)\end{array}$ \\
\hline T1 & 587 & $178 \mathrm{a}$ & $3.30 \mathrm{c}$ & $67 \mathrm{a}$ \\
$\mathrm{T} 2$ & 595 & $174 \mathrm{~b}$ & $3.42 \mathrm{~b}$ & $63 \mathrm{~b}$ \\
$\mathrm{~T} 3$ & 601 & $177 \mathrm{a}$ & $3.38 \mathrm{~b}$ & $66 \mathrm{a}$ \\
T4 & 617 & $172 \mathrm{bc}$ & $3.59 \mathrm{a}$ & $64 \mathrm{ab}$ \\
P-value & 0.120 & 0.041 & 0.039 & 0.035 \\
SEM & 31.018 & 3.012 & 0.105 & 2.589 \\
\hline
\end{tabular}

T1 - Control (basal) diet balanced on NRC (1994) recommendations; T2 - 15\% reduction in protein without antioxidant; T3 - 15\% reduction in protein plus E-selenium antioxidant; T4 - 15\% reduction in protein plus antioxidant Loxidan. SEM - standard error of the mean.

Means within each column with no common letter differ significantly $(\mathrm{P}<0.05)$.
E-selenium intake led to improved FBW in birds fed low-protein diets, showing approximately the same level as the control group. Nonetheless, such improvement was not observed in birds fed a low-protein diet with Loxidan supplementation, although an insignificant decrease was recorded, compared with the group fed a low protein diet. It is concluded that the amount of dietary protein is one of the effective factors in FBW; lower amounts of dietary protein resulted in a clear decrease in FBW, while intake of E-selenium, as a natural antioxidant, could improve FBW. In agreement with several studies (Hashiguchi and Yamamoto, 2006; Tarasewicz et al., 2007; Oliveira et al., 2013), the results from this study demonstrated that low levels of dietary protein lead to decreased FBW in broilers under different temperatures. Hashiguchi and Yamamoto (2006) reported that no significant differences were observed in FBW levels between groups receiving $24 \%$ and $19 \%$ dietary protein. However, the group fed diets containing $14 \%$ protein showed a significantly lower FBW than that fed diets containing $24 \%$ and $19 \%$ protein. Kamran et al. (2008) also showed that reduced crude protein diets lead to reduced FBW in broilers. Fan et al. (2009) demonstrated that diets supplemented with different levels of selenium have the ability to improve daily weight gains in broilers. Imik et al. (2010) demonstrated that the intake of vitamin E, vitamin $\mathrm{C}$, lipoic acid, and antioxidant combinations (vitamins $\mathrm{E}$ and $\mathrm{C}$ ) has no significant effect on weight gain in quail under heat stress conditions. We concluded that not only did FBW increase in quail fed antioxidants, but also E-selenium intake was more effective in FBW of Japanese quail, as compared with other antioxidants.

The best FCR, $3.30 \mathrm{~g} / \mathrm{g}$, was recorded in the control group. Quail fed a low-protein diet without antioxidants showed a significant increase $(\mathrm{P}<0.05)$ up to $3.42 \mathrm{~g} / \mathrm{g}$ in FCR, which is considered as a disadvantage index for the poultry industry. However, an insignificant increase was observed in quail fed a low-protein diet with E-selenium, as compared with those fed low-protein diets without antioxidant supplementation. In contrast, a significant

Table 3 - Effects of treatments on reproduction indices

\begin{tabular}{lccccc}
\hline Treatment & Serum testosterone $(\mathrm{ng} / \mathrm{mL})$ & Testis weight $(\%)$ & Spermatogonia $(\mathrm{n})$ & Spermatid $(\mathrm{n})$ & Spermatozoa $(\mathrm{n})$ \\
\hline T1 & $4.4 \mathrm{a}$ & $2.59 \mathrm{a}$ & $109 \mathrm{a}$ & $212 \mathrm{a}$ & $184 \mathrm{a}$ \\
T2 & $3.2 \mathrm{~b}$ & $2.15 \mathrm{~b}$ & $99 \mathrm{~b}$ & $204 \mathrm{~b}$ & $179 \mathrm{~b}$ \\
T3 & $2.6 \mathrm{~b}$ & $2.03 \mathrm{~b}$ & $107 \mathrm{a}$ & $211 \mathrm{a}$ & $182 \mathrm{ab}$ \\
T4 & $4.3 \mathrm{a}$ & $1.97 \mathrm{~b}$ & $107 \mathrm{a}$ & $211 \mathrm{a}$ & $182 \mathrm{ab}$ \\
P-value & 0.047 & 0.0384 & 0.028 & 0.0484 & 0.0451 \\
SEM & 0.105 & 0.135 & 5.151 & 6.125 & 3.010 \\
\hline
\end{tabular}

T1 - Control (basal) diet balanced on NRC (1994) recommendations; T2 - 15\% reduction in protein without antioxidant; T3 - 15\% reduction in protein plus E-selenium antioxidant; $\mathrm{T} 4-15 \%$ reduction in protein plus antioxidant Loxidan.

SEM - standard error of the mean.

Means within each column with no common letter differ significantly $(\mathrm{P}<0.05)$. 
increase $(\mathrm{P}<0.05)$ was found in quail fed a low-protein diet supplemented with Loxidan, showing an increase to $3.59 \mathrm{~g} / \mathrm{g}$. The present study revealed that antioxidant intake with low-protein diets could not improve FCR. Kamran et al. (2008) demonstrated that reduced crude protein diets are able to increase FCR in broilers. Reduced serum protein levels, due to reduced protein diets, are one of the reasons for reduced performance (Surai, 2007). Additionally, Oliveira et al. (2013) reported that reduced crude protein diets lead to increased FCR levels in broilers under different temperatures. Fan et al. (2009) demonstrated that intake of different concentrations of selenium results in improved FCR in broilers. Consistent with our results, Imik et al. (2010) reported that antioxidants have no significant effects on feed intake and FCR of quail.

The reduction of the dietary protein caused suppression in carcass dressing percentage $(\mathrm{P}<0.05)$ (Table 2), while intake of both antioxidants, particularly E-selenium, effectively increased the carcass yield in the low-protein $\operatorname{diet}(\mathrm{P}<0.05)$, although previous studies have not examined this item and there is no report.

Reduced dietary protein levels led to a significant decrease $(\mathrm{P}<0.05)$ in serum testosterone concentrations, as compared with the control group. A 15\% decrease in dietary protein levels yielded a decrease in serum testosterone concentrations from 4.4 (control) to $3.2 \mathrm{ng} / \mathrm{mL}$ (low protein diet without antioxidants) (Table 3). E-selenium intake was unable to prevent the reduction of serum testosterone concentrations under the influence of protein reduction, whereas Loxidan intake could potentially compensate for the adverse effects of dietary protein reduction in serum testosterone concentrations $(\mathrm{P}<0.05)$. It can be deduced that Loxidan intake could prevent reduced serum testosterone concentrations under the influence of protein reduction. This is in agreement with the study performed by Khaki et al. (2009), which reported that antioxidant properties of ginger significantly increase serum total testosterone levels $(\mathrm{P}<0.05)$. However, this result was not observed in the quail fed E-selenium.

A significant decrease $(\mathrm{P}<0.05)$ in the mean weight of testes was detected in birds fed a low-protein diet without antioxidants, as compared with the control group (Table 3). Consistent with our study, Tarasewicz et al. (2007) showed that lower levels of dietary protein are associated with decreased testis weight in quail. Meanwhile, birds fed both E-selenium with low protein diets or Loxidan with low protein diets showed no significant difference compared with those fed a low protein diet without antioxidant supplementation $(\mathrm{P}<0.05)$. It can be concluded that reduced dietary protein resulted in significantly decreased $(\mathrm{P}<0.05)$ mean testis weight in experimental treatments, compared with the control group.

The mean number of spermatogonia in the group fed a low-protein diet without antioxidants showed a significant decrease $(\mathrm{P}<0.05)$ compared with the control group. Quail fed low-protein diets containing either E-selenium or Loxidan showed significant enhancement $(\mathrm{P}<0.05)$ compared with those fed a low-protein diet without antioxidant supplementation. We concluded that antioxidant intake significantly increases $(\mathrm{P}<0.05)$ the number of spermatogonia. Consistent with our results, Khaki et al. (2009) demonstrated that the antioxidant property of ginger had a useful effect on spermatogenesis and sperm parameters.

Birds fed a low-protein diet without antioxidant supplementation exhibited a significant drop $(\mathrm{P}<0.05)$ in the number of spermatid cells. In other words, reduced dietary protein resulted in a significant decrease $(\mathrm{P}<0.05)$ in the number of spermatid cells in testicular tissue. Similar to the control group, quail receiving antioxidants exhibited an increase $(\mathrm{P}<0.05)$ in the number of spermatid cells (Figure 3). Quail fed low-protein diets supplemented with both E-selenium and Loxidan could successfully compensate for the number of spermatid cells. Oxidative stress results from the production of oxygen radicals in stressed tissues that possess no antioxidant capacity (Turner and Lysiak, 2008). Ghosh et al. (2002) revealed that vitamins $\mathrm{C}$ and $\mathrm{E}$ have the ability to ameliorate oxidative stress-related testicular impairment in animal tissues.

The mean number of spermatozoa showed a significant decrease $(\mathrm{P}<0.05)$ in the group fed a low-protein diet without

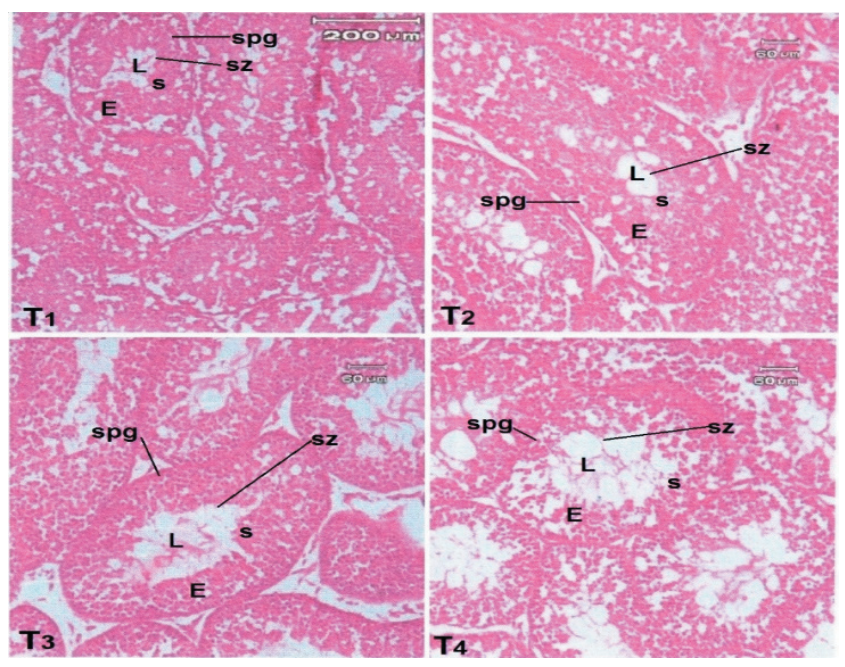

Figure 3 - Cross section (100x magnification) of seminiferous tubules, showing the presence of Lumen (L), epithelium (E), spermatid (s), spermatogonia (SPG), and spermatozoa (SZ). 
antioxidant supplementation. The number of spermatozoa cells was reduced from 184 in the control group to 179 in the group fed a low-protein diet without antioxidants. In addition, a significant increase $(\mathrm{P}<0.05)$ was found in the number of spermatozoa in quail fed antioxidants, as compared with those fed low-protein diets. Both groups fed antioxidants, either E-selenium or Loxidan, had the same number of spermatozoa. It can be concluded that antioxidant intake could compensate for a $15 \%$ reduction in dietary protein.

Because spermatozoa are vulnerable to lipid peroxidation due to their fatty acid structure, dietary protein decrease, which reduces the antioxidant system, needs to be compensated for by antioxidant intake (Surai, 2007). In a study, it was found that vitamin E protects spermatozoa against oxidant effects because of its antioxidant properties (Surai et al., 2002). Edens and Sefton (2009) indicated that diets supplemented with selenium are able to improve normal spermatozoa percentages.

\section{Conclusions}

The intake of both antioxidants, Loxidan and E-selenium, leads to significantly improved pathological indexes of testicular tissue (the number of spermatogonia, spermatid, and spermatozoa) as well as serum testosterone levels in male Japanese quail fed low-protein diets.

\section{Acknowledgments}

The authors would like to thank the Damavand Quail Co. (www.dquail.ir), Tehran, Iran, for equipment of the experimental room of Japanese quail in Tabriz, Iran.

\section{References}

Baylan, M.; Canogullari, S.; Ayasan, T. and Copur, G. 2011. Effects of dietary selenium source, storage time, and temperature on eggshell internal quality in quail eggs. Biological Trace Elements Research 143:957-964

Canogullari, S.; Ayasan, T.; Baylan, M. and Çopur, G. 2010. The effect of organic and inorganic selenium supplementation on egg production parameters and egg selenium content of laying Japanese quail. Journal of the Faculty of Veterinary Medicine, Kafkas University 16:743-749.

Duncan, D. B. 1955. Multiple range and multiple F test. Biometrics $11: 1-42$.

Edens, F. W. and Sefton, A. E. 2009. Sel-Plex ${ }^{\circledR}$ improves spermatozoa morphology in broiler breeder males. International Journal of Poultry Science 8:853-861.

Fan, C.; Yu, B. and Chen, D. 2009. Effects of different sources and levels of selenium on performance, thyroid function and antioxidant stressed broiler chickens. International Journal of Poultry Science 8:583-587.
Ghosh, D.; Das, U. B. and Mishra, M. 2002. Protective role of $\alpha$ tochopherol succinate (pro-vitamin E) in cyclophasphamide induce testicular gemitogenic steroidogenicdisorders. Journal of Radiation Research 36:1199-1208.

Hashiguchi, M. and Yamamoto, Y. 2006. Effect of dietary protein levels on body growth and carcass fat and protein deposition in female Japanese quail. Proceedings of 12th European Poultry Conference, Verona, Italy. Journal of EPC 269-272.

Imik, H.; Aydemir A. M.; Koc, M.; Atasever, M. and Ozturan, K. 2010. Effect of dietary supplementation of some antioxidants on growth performance, carcass composition and breast meat characteristics in quails reared under heat stress Czech Journal Animal Science 55:209-220

Kamran, Z.; Sarwar, M.; Mahr-Un-N.; Nadeem, M. A. and Mahmood, S. 2010. Effect of low levels of dietary crude protein with constant metabolizable energy on nitrogen excretion, litter composition and parameters of broilers. International Journal of Agriculture \& Biology 14:401-405.

Kamran, Z.; Sarwar, M.; Nisa, M.; Nadeem, M. A.; Mahmood, S. Babar, M. E. and Ahmed, S. 2008. Effect of low-protein diets having constant energy-to-protein ratio on performance and carcass characteristics of broiler chickens from one to thirty-five days of age. Journal of Poultry Science 87:468-474.

Khaki, A.; Fathiazad, F.; Nouri, M.; Khaki, A. A.; Chelar, C.; Ozanci, C. C.; Ghafari-Novin, M. and Hamadeh, M. 2009. The effects of ginger on spermatogenesis and sperm parameters of rat. Iranian Journal of Reproduction Medicine 7:7-12.

Khakpour, S.; Minaee, M.; Fazelipour, S. and Zarrabian, S. 2012. Effects of Citrus aurantium extract on spermatogenic cell density, antioxidant activity and testosterone level in male mice. African Journal of Pharmacy and Pharmacology 6:480-486.

NRC - National Research Council. 1994. Nutrient requirements of poultry. 9th rev. ed. National Academy Press, Washington, D.C.

Oliveira, W. P.; Oliveira, R. F. M.; Donzele, J. L.; Oliveira Neto, A. R.; Gomes, P. C.; Maia, A. P. A.; Campos, P. H. R. F. and Gasparino, E. 2013. Dietary crude protein reduction on growth and carcass performance of 22 to 42-day-old broilers reared under different temperatures. Revista Brasileira de Zootecnia 42:599-604.

Pryor, W. A.; Houk, K. N.; Foote, C.S.; Fukuto, J. M.; Ignarro, L. J.; Squadrito, G. L. and Davies K. J. A. 2006. Free radical biology and medicine: it's a gas, man! American Journal of Physiological Regulatory Integrative and Comparative Physiology 291:R491R511.

Rengaraj, D. and Hong, Y. H. 2015. Effects of dietary vitamin E on fertility functions in poultry species. International Journal of Molecular Science 16:9910-9921.

Surai, P. F. 2007. Natural antioxidants in poultry nutrition: new developments. p.669-676. In: Proceedings of the 16th European Symposium on Poultry Nutrition. Strasbourg, France.

Surai, P. F.; Dvorska J. E.; Sparks, N. H. C. and Jacques, K. A. 2002. Impact of mycotoxins on the body's antioxidant defence. In: Proceedings of Alltech's 18th Annual Symposium. Kentucky, USA.

Surai, P. F.; Karadas, F. and Sparks, N. H. 2003. The importance of antioxidants in poultry. Avian Science Research Centre, SAC, Auchincruive, Ayr, Scotland, UK and Department of Animal Science, Yuzuncu Yil University, Turkey.

Tarasewicz, Z.; Gardzielewska, J.; Szczerbińska, D.; Ligocki, M.; Jakubowska, M. and Majewska, D. 2007. The effect of feeding with low protein feed mixes on the growth and slaughter value of young male Pharaoh quails. Archives Animal Breeding 50:520-530.

Tarasewicz, Z.; Szczerbinska, D.; Ligocki, M.; Wiercinska, M.; Majewska, D. and Romaniszyn, K. 2006. The effect of differentiated dietary protein level on the performance of breeder quails. Animal Science Papers and Reporter 24:207-216. 
Turner, T. T. and Lysiak, J. J. 2008. Oxidative stress: a common factor in testicular dysfunction. Journal of Andrology 29:488-498.

Vahdatpour, T. and Babazadeh, D. 2016. The effects of kefir rich in probiotic administration on serum enzymes and performance in male Japanese quails. The Journal of Animal and Plant Science 26:34-39.
Vahdatpour, T.; Nazeradl, K.; Ebrahimnezhad, Y.; Maheri-sis, N.; Reyazi, S. R. and Vahdatpour, S. 2009. Effects of corticosterone intake as stress-alternative hormone on broiler chickens: Performance and blood parameters. Asian Journal of Animal and Veterinary Advances 4:16-21. 